\title{
A NEW SPECIES OF GOBIID FISH,LUCIOGOBIUS FROM RYUKYUS, JAPAN(TELEOSTEI: GOBIIDAE)
}

I-Shiung Chen

Institute of Marine Biology, National Taiwan Ocean University, Keelung 202, Taiwan, R.O.C., isc@mail.ntou.edu.tw

Toshiyuki Suzuki

Amagasaki Senoir High School, 5-40-1, Tsukaguchimachi, Amagasaki, Hyogo, 661-0002 Japan., suzuki-

toshiyuki@pop21.edn.ne.jp

Hiroshi Senou

Kanagawa Prefectural Museum of Natural History, 499, Iryuda, Odawara, Kanagawa 250-0031, Japan., senou@nh.kanagawa-museum.jp

Follow this and additional works at: https://jmstt.ntou.edu.tw/journal

Part of the Marine Biology Commons

\section{Recommended Citation}

Chen, I-Shiung; Suzuki, Toshiyuki; and Senou, Hiroshi (2008) "A NEW SPECIES OF GOBIID FISH,LUCIOGOBIUS FROM RYUKYUS, JAPAN(TELEOSTEI: GOBIIDAE)," Journal of Marine Science and Technology. Vol. 16: Iss. 4, Article 2. DOI: $10.51400 / 2709-6998.2005$

Available at: https://jmstt.ntou.edu.tw/journal/vol16/iss4/2

This Research Article is brought to you for free and open access by Journal of Marine Science and Technology. It has been accepted for inclusion in Journal of Marine Science and Technology by an authorized editor of Journal of Marine Science and Technology. 


\section{A NEW SPECIES OF GOBIID FISH,LUCIOGOBIUS FROM RYUKYUS, JAPAN(TELEOSTEI: GOBIIDAE)}

\section{Acknowledgements}

First author (ISC) wishes to thank the research grant support of governmental from National Science Council for 2006, Taipei, ROC and the assistance of preparing table of meristic data by Mr. Shih-Bing Huang (Institute of Wildlife Conservation, National Pingtung University of Science and Technology). Second author (TS) wishes to thank Mr. Korechika Yano (Dive Service Yano, Iriomote-jima Island, Okinawa, Japan) who provided the alive photo image of Luciogobius species, and Mr. Masahiro Aizawa (Biological Laboratory, Imperial Household, Tokyo) who could give the useful and constructive advice about genus Luciogobius from Japanese waters, and Mr. Masatomi Suzuki (Hyogo, Japan) who cooperated with collection of the cypes. 


\title{
A NEW SPECIES OF GOBIID FISH, LUCIOGOBIUS FROM RYUKYUS, JAPAN (TELEOSTEI: GOBIIDAE)
}

\author{
I-Shiung Chen*, Toshiyuki Suzuki**, and Hiroshi Senou***
}

Key words: new goby, Luciogobius, fish fauna, fish taxonomy, Japan.

\begin{abstract}
A new gobiid fish has been collected from Ryukyu Archipelagos of Japan. This species is described herein as a new species, Luciogobius ryukyuensis sp. nov. It is characterized by the following unique combination of features: (1) second dorsal fin rays: I/11 and anal fin rays I/11; (2) pectoral fin rays 16 and with one upper, very short free soft ray; (3) vertebral count 37; and (4) specific coloration: head and body with many rounded light creamy white spots above creamy yellow to yellowish brown background. A diagnostic key to all nominal species of Luciogobius from West Pacific are provided herein.
\end{abstract}

\section{INTRODUCTION}

The gobiid fishes in Family Gobiidae comprise the most diverse group among teleost (Miller [11], Chen and Kottelat [5]). The great diversity of longitudinal gobioid fauna with higher vertebral count is mostly endemic to West Pacific and north-western Pacific. For example, the genus Luciogobius and other related genera is typically belonging to Eastern Asiatic, Japanese-Taiwanese-Chinese-Korean endemic in the freshwater to marine habitats (Akihito et al. [2], Suzuki and Shibukawa [18], Chen and Fang [4]). In Japanese waters, there are 12 nominal species have been revised as valid (Shiogaki and Dotsu [16], Okiyama [12], Akihito et al. [2]) and but there are still more than 20 undescribed species of the genus (Suzuki and Shibukawa [18]).

The uncovered, current species of Luciogobius from the Ryukyu and Amami O-shima Archipelagos have been considered as valid, undescribed herein which was first collected in 1980 by the second and third author (TS and HS). Recently, first author (ISC) had tried to revise this genus in Taiwan have yielded at least 2 undescribed species of Luciogobius (Chen,

Paper submitted 06/22/07; accepted 09/06/07. Author for correspondence: I-Shiung Chen (e-mail: isc@mail.ntou.edu.tw).

* Institute of Marine Biology, National Taiwan Ocean University, Keelung 202, Taiwan, R.O.C.

** Amagasaki Senoir High School, 5-40-1, Tsukaguchimachi, Amagasaki, Hyogo, 661-0002 Japan. (email: suzuki-toshiyuki@pop21.edn.ne.jp)

***Kanagawa Prefectural Museum of Natural History, 499, Iryuda, Odawara, Kanagawa 250-0031, Japan. (email: senou@nh.kanagawa-museum.jp) unpublished data). One of our cooperative projects is to settle down the taxonomic status of species collections of Luciogobius from the Ryukyus which geographically is in bridge the mainland Japan and Taiwan, and the result seems to support that it is an undescribed species which is rather differed to all nominal species in Japan. Based on the reason of our cooperative project of this genus and also for very serious concern of its biodiversity conservation issue which has been listed as the endangered species on red-list of Japan, the real requirement for publishing such morphological distinct taxon is very essential and important for further governmental strategy and management of aquatic ecological conservation of endemic species of Japan. Herein we describe this one of Ryukyu as new species from Japanese waters. An artificial key for all nominal species from Japan are also provided within this paper.

\section{MATERIALS AND METHODS}

All type specimens of the new species were collected by second author (TS). All counts and measurements were made from specimens preserved in $70 \%$ ethanol. Morphmoetric methods follow Miller [11] and meristic methods follow Akihito et al. [1], Chen and Shao [6], Chen and Kottelat [5]. Terminology of cephalic sensory canals and free neuromast organ (sensory papillae) is from Wongrat and Miller [20], based on Sanzo [15].

Type specimens and comparative materials are deposited at Osaka Museum of Natural History, Osaka (OMNH) and Yokosuka City Museum, Yokosuka (YCM). Meristic abbreviations: A, anal fin; C, caudal fin; D1, and D2, 1st and 2nd dorsal fins respectively; $\mathrm{P}$, pectoral fin; V, pelvic fin; and $\mathrm{VC}$, vertebral count. All fish lengths are standard length (SL).

\section{SYSTEMATICS}

\section{Luciogobius ryukyuensis Chen, Suzuki and Senou new species}

(Japanese name: Minami-hime-mimizuhaze)

(Figs. 1, 2 and 3)

Luciogobius sp. 1 Suzuki et Shibukawa, 2004: 60.

Luciogobius sp. Suzuki, Sakamoto et Senou, 2006:199.

\section{Materials examined}

Holotype. OMNH-P 20480, $33.5 \mathrm{~mm}$ SL, upper end of tidal region, Aira-gawa River, Iriomote Island, Japan, Dec. 28, 1990, 


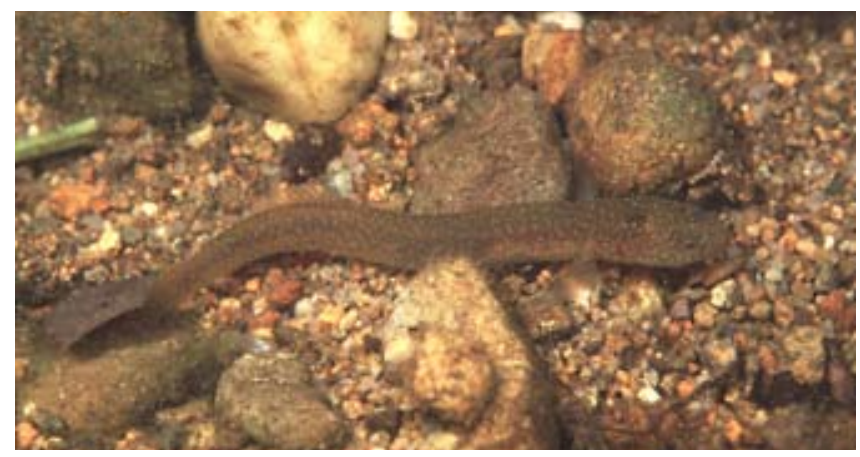

Fig. 1. Alive photo of Luciogobius ryukyuensis, about $45 \mathrm{~mm} \mathrm{SL,} 30 \mathrm{~cm}$ depth, Aira-gawa River, Iriomote Island, Japan. Photograph by Mr. Korechika Yano.

coll. T. Suzuki and M. Suzuki.

Parartypes. NTOUP 2007-07-068, 2 specimens, 37.4-37.6 mm SL, Makiyaokawa-gawa River, Okinawa Island, Japan, July 17, 2006, coll. T. Suzuki et al. (originally from OMNH-P 31324). OMNH-P 20481, $35.2 \mathrm{~mm}$ SL, upper end of tidal region, Aira-gawa River, Iriomote Island, Japan, Dec. 28, 1990, coll. T. Suzuki and M. Suzuki. OMNH-P 20482, 2 specimens, 32.2-33.4 mm SL, upper end of tidal region, Aira-gawa River, Iriomote Island, Japan, Dec. 28, 1990, coll. T. Suzuki and M. Suzuki. OMNH-P 20484, 3 specimens, 21.6-26.6 mm SL, middle reaches of Aira-gawa River, Iriomote Island, Japan, Aug. 11, 1991, coll. T. Suzuki and M. Suzuki. OMNH-P 20508, 37.1 $\mathrm{mm}$ SL, middle reaches of Aira-gawa River, Iriomote Island, Japan, July 21, 1998, coll. T. Suzuki and M. Suzuki. OMNH-P 20509, $38.7 \mathrm{~mm}$ SL, middle reaches of Aira-gawa River, Iriomote Island, Japan, July 21, 1998, coll. T. Suzuki and M. Suzuki. OMNH-P 20510, 12 specimens, 25.7-35.8 mm SL, middle reaches of Aira-gawa River, Iriomote Island, Japan, July 21, 1998, coll. T. Suzuki and M. Suzuki. OMNH-P 20523, 41.2 $\mathrm{mm}$ SL, upper end of tidal region, Nishifonera-gawa River, Iriomote Island, Japan, Aug. 15, 2001, coll. T. Suzuki and M. Suzuki. OMNH-P 20524, 39.6 mm SL, upper end of tidal region, Nishifonera-gawa River, Iriomote Island, Japan, Aug. 15, 2001, coll. T. Suzuki and M. Suzuki. OMNH-P 20525, 6 specimens, 26.4-33.6 mm SL, upper end of tidal region, Nishifonera-gawa River, Iriomote Island, Japan, Aug. 15, 2001, coll. T. Suzuki and M. Suzuki. OMNH-P 20528, 5 specimens, 23.6-28.8 mm SL, upper end of tidal region, Nishifonera-gawa River, Iriomote Island, Japan, Aug. 15, 2001, coll. T. Suzuki and M. Suzuki. OMNH-P 31323, $45.4 \mathrm{~mm}$ SL, data same as NTOUP 2007-07-068.

Non-types.- YCM-SSP 9126, 36 specimens, 21.5-38.3 mm SL, Aira-gawa River, Iriomote Island, Japan, July 21, 1980, coll. T. Suzuki and H. Senou; YCM-SSP 9127, 14 specimens, 16.8-25.0 mm SL, Maera-gawa River, Iriomote Island, Japan, July 22, 1980, coll. T. Suzuki and H. Senou.

\section{Diagnosis}

Luciogobius ryukyuensis can be distinguished by the all other congeneric species by the following unique combination of features: (1) second dorsal fin rays: I/11 and anal fin rays I/11; (2) pectoral fin rays modally 16 and with one upper, very short

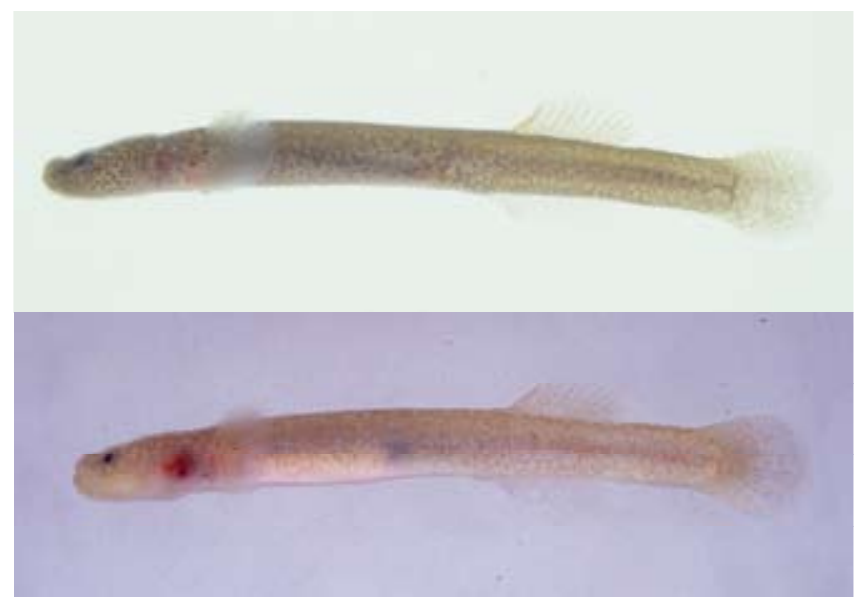

Fig. 2. Luciogobius ryukyuensis, Above holotype, male, OMNH-P 20480 $33.5 \mathrm{~mm}$ SL, and Below paratype, female, OMNH-P 20524, 39.6 mm SL.

free soft ray; (3) vertebral count: $16+21=37$; and (4) specific coloration: head and body with many rounded light creamy white spots above creamy yellow background.

\section{Description}

Body very slender, cylindrical anteriorly and somewhat compressed posteriorly (All morphometric data is shown in Table 1). Head flat and depressed. Cheek slightly fleshy.

Eye moderate small. A horizontal dermal fold on upper part of cheek and below orbit.

Snout flat and short. Anterior nasal opening as a protruded, horizontal short tube and posterior nasal opening as a round hole. Interorbital region rather wide, about two times of eye diameter. Mouth oblique, maxillary extending to vertical of rear margin of orbit. Lower jaw more prominent compared to upper jaw. Teeth rather minute, with 4-5 rows of tiny conical teeth which outer rows larger in both jaws. Tongue somewhat pointed, but the anterior tip bilobed. Gill opening rather restricted, extending merely slightly below lower margin of pectoral base. Anus located in posterior half of body. Vertebral count $16+21=$ 37 (counted by X-rays from 18 type specimens).

Fins. D2 I/11(18), A I/11(18), P 15(1)-16(17) (all counted from 18 specimens). D1 absent. D2 with the middle one third portion of rays longest. A shape similar to D2. Both first spines in D2 and A relatively short. A origin in front of D2 origin. D2 origin inserted the vertical through between 2 nd and 3 rd branched rays of A. Both rear tip of D2 and A is far from the procurrent rays of $\mathrm{C}$ when depressed. $\mathrm{P}$ rounded and its length about equal to postorbital length. $\mathrm{P}$ with a short, free soft ray on upper margin near upper basal region. $\mathrm{C}$ rounded. $\mathrm{V}$ as a round sucking disc with complete frenum and rather small which just somewhat larger than orbit, but smaller than snout length.

Scales. Both body and head entirely naked without any scale.

Head lateral-line system (Fig. 3). Head canals: whole head in lacking any canal and head pores. Sensory papillae: the series of infraorbital sensory papillae all representing typically longitudinal pattern. Row $a$ long and extending to snout which upward 


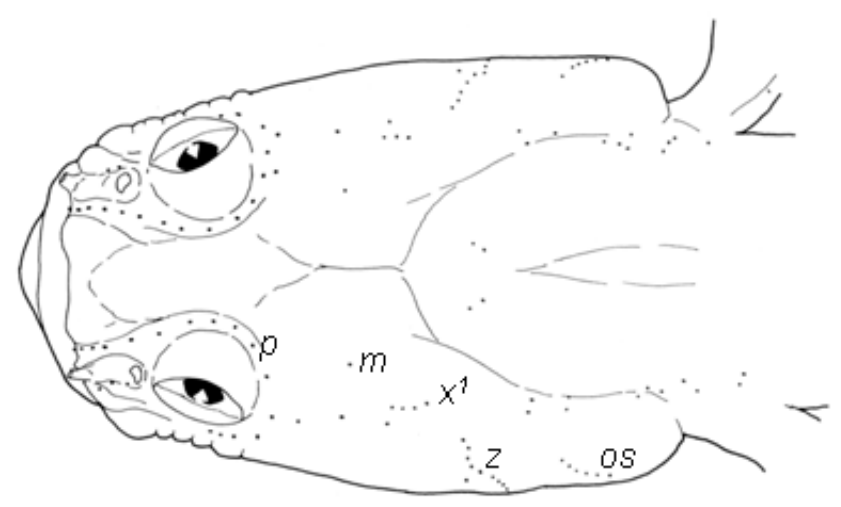

Table 1. Morphometry of Luciogobius ryukyuensis.

\begin{tabular}{|c|c|c|c|}
\hline Morphometric characters & MIN & MAX & $\begin{array}{l}\text { Avcragc } \\
(\mathrm{n}=12)\end{array}$ \\
\hline \multicolumn{4}{|l|}{$\begin{array}{c}\text { Percent standard length } \\
(\% \mathrm{SL})\end{array}$} \\
\hline Head length & $19.7 \%$ & $21.2 \%$ & $22.1 \%$ \\
\hline Snout to 2 nd dorsal origin & $65.7 \%$ & $70.2 \%$ & $67.7 \%$ \\
\hline Snout to anus & $57.7 \%$ & $61.2 \%$ & $59.1 \%$ \\
\hline Snout to anal fin origin & $62.6 \%$ & $61.7 \%$ & $63.8 \%$ \\
\hline Prepelvic length & $20.0 \%$ & $21.5 \%$ & $21.2 \%$ \\
\hline Caudal penduncle length & $20.0 \%$ & $21.2 \%$ & $22.5 \%$ \\
\hline Caudal penduncle depth & $7.7 \%$ & $9.1 \%$ & $8.6 \%$ \\
\hline 2nd dorsal fin base & $11.6 \%$ & $17.3 \%$ & $16.1 \%$ \\
\hline Anal fin base & $15.6 \%$ & $18.7 \%$ & $16.5 \%$ \\
\hline Caudal fin length & $12.8 \%$ & $11.5 \%$ & $11.2 \%$ \\
\hline Pectoral fin length & $10.7 \%$ & $11.2 \%$ & $12.5 \%$ \\
\hline Pelvic fin length & $1.7 \%$ & $6.3 \%$ & $5.5 \%$ \\
\hline Body depth at pelvic fin origin & $9.5 \%$ & $12.2 \%$ & $10.7 \%$ \\
\hline Body depth at anal fin origin & $9.1 \%$ & $12.1 \%$ & $11.0 \%$ \\
\hline Body width at anal fin origin & $6.2 \%$ & $7.8 \%$ & $6.8 \%$ \\
\hline Pelvic fin origin to anus & $35.8 \%$ & $39.5 \%$ & $38.0 \%$ \\
\hline \multicolumn{4}{|l|}{ Percent head length (\% HL) } \\
\hline Snout length & $23.6 \%$ & $28.0 \%$ & $26.1 \%$ \\
\hline Eye diameter & $11.1 \%$ & $16.3 \%$ & $13.6 \%$ \\
\hline Cheek depth & $17.3 \%$ & $21.6 \%$ & $20.2 \%$ \\
\hline Postorbital length & $59.3 \%$ & $67.5 \%$ & $61.2 \%$ \\
\hline Head width in maximum & $11.1 \%$ & $53.7 \%$ & $19.7 \%$ \\
\hline Head width in upper gill & $30.3 \%$ & $38.6 \%$ & $31.7 \%$ \\
\hline Bony interorbital width & $11.2 \%$ & $16.3 \%$ & $13.5 \%$ \\
\hline Fleshy interorbital width & $21.6 \%$ & $28.2 \%$ & $21.8 \%$ \\
\hline Lower jaw length & $37.0 \%$ & $13.5 \%$ & $10.7 \%$ \\
\hline
\end{tabular}

surrounded eye diameter in interoribtal region. Row $b$ rathe long starting on anterior portion of dermal ridge. Row $c$ mainly below the dermal fold and rather long. A single $c p$ located below rear Row $c$. Row $d$ slightly shorter than row $c$. Rows $z$ and $o t$ seems to be connected together. Row $f$ paired only as two papillae. Opercle with three rows $o t, o s$, and $o i$. Rows $o s$ and $o t$ well separated. Rows $z$ and ot connected together as single vertical row. Other papillae are shown in detail in Fig. 3.

Coloration when fresh.- Based on the fresh specimens from Iriomote Island (Figs. 1 and 2), the body and head light creamy yellow to yellowish brown background. Head and body with many rounded light creamy white spots which about equal to the size of pupil. Belly spotless, uniform pale white or creamy white. Caudal fin with many light brown spots. Other fins pale yellow and translucent, spotless, and darker in rays of D2 and A. The specimens while in alcoholic preservation have yielded uniformly light, pale yellow. The round light spots on head and body are faded and indistinct except a few still can be observed

PS: MIN: minimum; MAX: maximum

on dorsal head.

\section{Distribution}

This species (formerly Luciogobius sp. 1) have been found and observed from several localities including the Amami O-shima, Okinawa, Ishigaki and Iriomote islands of southern Japan (Suzuki and Shibukawa [18]) although the type series are currently based on gobiid specimens from Iriomote Island. It is highly possible to be the Ryukyu endemic since no further specimens record from mainland Japan and Taiwan.

\section{Habitats}

This species inhabits among gravels at the rapids which are in the most lower reaches in the freshwater area on the river. 


\section{Etymology}

The specific name, ryukyuensis, is referred to the type locality from Ryukyu Archipelagos, Japan.

\section{Remarks}

This new species, Luciogobius ryukyuensis, shares the typical longitudinal pattern of infraorbital sensory papillae, rather slender body and lacking first dorsal fin as all congeneric species of Japan and China (Gill [10], Chen [7], Di Caporiacco [8], Akihito et al. [2], Suzuki and Shibukawa [18]). In Japanese Archipelagos, Luciogobius ryukyuensis can be immediately separated from species group with small scales on caudal peduncle including: Luciogobius ama (Snyder, 1909) [17] and Luciogobius koma (Snyder, 1909) [17], and the new species is well differed to recently described species, Luciogobius adapel Okiyama, 2001 [12] which lacks the dorsal and anal fins.

Luciogobius ryukyuensis share the feature as anal fin origin in front of second dorsal fin origin with following five species: Luciogobius guttatus Gill, 1859 [10], Luciogobius elongatus Regan, 1908 [13], Luciogobius parvulus (Snyder, 1909) [17], Luciogobius grandis Arai, 1970 [3], and Luciogobius platycephalus Shiogaki et Dotu, 1976 [16], and unlike other four remaining species with second dorsal fin origin in front of anal fin origin including following four species: Luciogobius albus Regan, 1940 [14], Luciogobius pallidus Regan, 1940 [14], Luciogobius saikaiensis Dotu, 1957 [9], and Luciogobius dromitoris Shiogaki et Dotu, 1976 [16] respectively.

Luciogobius ryukyuensis is rather similar to Luciogobius guttatus than four remaining congeneric species in body and pectoral fin shape. Luciogobius ryukyuensis is rather differed to Luciogobius parvulus by the presence of pelvic fin vs. absence of that. Luciogobius ryukyuensis is also well differentiated with Luciogobius elongatus as one free soft ray on upper margin of pectoral fin vs. absence of any free rays of pectoral fin, and second dorsal fin I/11 vs. I/6. Luciogobius ryukyuensis can be distinguished from the following two species including Luciogobius grandis and Luciogobius platycephalus by pectoral fin merely with one free ray vs. representing 2-5 free soft rays on upper margin.

The two published nominal species of Chinese waters share the similar feature of this Japanese endemic Luciogobius ryukyuensis with normal size of eyes. However, Luciogobius ryukyuensis is differed from Luciogobius brevipterus Chen, 1932 [7] by second dorsal fin rays I/11 vs. I/13; anal fin rays I/11 vs. I/13; and pectoral fin length in head 1.6-1.9 (average 1.8) vs. 2.5 Luciogobius ryukyuensis can be well distinguished from Luciogobius martellii Di Caporiacco, 1947 [8] by pectoral fin rays modally 16 vs. 19 . However, we considered that $L$. martellii Di Caporiacco, 1947 [8] should be a junior synonym of Luciogobius guttatus Gill, 1859 [10] (Chen, unpublished data).

Therefore, Luciogobius ryukyuensis can be well distinguished from very common, closely related species: Luciogobius guttatus of Japan by following features: (1) second dorsal fin rays: I/11 vs. modally I/12; (2) anal fin rays: I/11 vs. I/13; (3) Pectoral fin rays: modally 16 vs. modally $18-19$; (4) vertebral count: $16+21=37$ vs. $17+21=38$; and (5) head shape: somewhat square in dorsal view and cheek slightly fleshy vs. elliptical in dorsal view and cheek very fleshy in male; (6) coloration: creamy yellow background vs. brown to deep brown background. So far, this genus is still needed to be revised not only Japanese but also Taiwanese and Chinese waters where very few nominal species had been formerly recorded.

\section{Diagnostic key for all nominal species of genus, Luciogobius from West Pacific}

1. body in lacking dorsal and anal fins ------------------- adapel

- body with second dorsal and anal fins ------------------------ 2

2. body at least with scales on caudal peduncle ----------------- 3

- body entirely naked ------------------------------------------ 4

3. D2 I/10; P base with a vertical black bar ----------------- koma

- D2 I/8-9; P base without such mark ---------------------- ama

4. dermal ridge on cheek with barbels ----------------- sakaiensis

- dermal ridge on cheek no barbels ----------------------------- 5

5. eye reduced and embedded beneath skin; D2 origin in front of A origin -- 6

- eye normal size and not embedded; A origin in front of D2 origin -------------------------------------------------------- 8

6. D2 I/9; head length 25\% ----------------------------------- albus

- D2 I/10-11; head length about 20\% --------------------------- 7

7. D2 modally I/10; body depth about $12-13 \%$------ dormitoris

- D2 modally I/11; body depth about $10 \%$------------ pallidus

8. V absent ---------------------------------------------------- parvulus

- V present ---------------------------------------------------- 9

9. D2 modally 6 soft rays; $P$ in lacking any upper free soft ray ----------------------------------------------------------- elongatus

- D2 more than 10 soft rays; P at least with 1 or more upper free soft rays ---------------------------------------------------- 10

10. 1 free soft ray near upper basal origin of $\mathrm{P}$------------------ 11

- 2-5 free soft rays on upper margin of $\mathrm{P}$------------------- 13

11. D2 modally I/13; HL/P 2.5 ------------------------- brevipterus

- D2 modally I/11-12; HL/P 1.7-2.0 ------------------------ 12

12. D2 modally I/12; A modally I/13; P modally 18-19; VC 38 guttatus

- D2 I/11; A I/11; P modally 16; VC 37 ----------- ryukyuensis

13. $\mathrm{P}$ with 2-3 free soft rays on lower margin; D2 I/15; A I/15

$\mathrm{P}$ in lacking free rays on lower margin; D2 I/10; A I/14 platycephalus

\section{ACKNOWLEDGMENTS}

First author (ISC) wishes to thank the research grant support of governmental from National Science Council for 2006, Taipei, ROC and the assistance of preparing table of meristic data by Mr. Shih-Bing Huang (Institute of Wildlife Conservation, National Pingtung University of Science and Technology). Second author (TS) wishes to thank Mr. Korechika Yano (Dive Service Yano, Iriomote-jima Island, Okinawa, Japan) who provided the alive photo image of Luciogobius species, and $\mathrm{Mr}$. Masahiro Aizawa (Biological Laboratory, Imperial Household, Tokyo) who could give the useful and constructive advice about genus Luciogobius from Japanese waters, and Mr. Masatomi Suzuki (Hyogo, Japan) who cooperated with collection of the cypes. 


\section{REFERENCES}

1. Akihito, P., Hayashi, M., and Yoshino, T., "Suborder Gobioidei", in: Masuda, H., Amaoka, K., Araga, C., Uyeno, T. and Yoshino, T. editors, The fishes of Japanese Archipelagos, Tokai University Press, Tokyo (1984).

2. Akihito, Sakamoto. K., Ikeda, Y., and Sugiyama, K., "Suborder Gobioidei," in: Nakabo, T., editor, Fishes of Japan with Pictorial Keys to the Species, 2nd edition, Tokai University Press, Tokyo (2002).

3. Arai, R., "Luciogobius grandis, a new goby from Japan and Korea," Bulletin of National Science Museum (Tokyo), Vol. 13, pp. 199-206 (1970).

4. Chen, I-S. and Fang, L. S., The Freshwater and Estuarine Fishes of Taiwan, National Museum of Marine Biology and Aquarium Press, Pingtung (1999).

5. Chen, I-S. and Kottelat, M., "Four new freshwater gobies of the genus Rhinogobius (Teleostei: Gobiidae) from northern Vietnam," Journal of Natural History, Vol. 39, pp. 1047-1429 (2005).

6. Chen, I-S. and Shao, K. T., "A taxonomic review of the gobiid fish genus Rhinogobius Gill, 1859, from Taiwan, with descriptions of three new species," Zoological Studies, Vol. 35, pp. 200-214 (1996).

7. Chen, J. T. F., "Note sur un nouveau poisson chinois appartenant au genre Luciogobius," Bulletin du Museum National d'Histoire Naturelle (Série 2), Vol. 4, pp. 648-650 (1932).

8. Di Caporiacco, L., "Miscellanea ichthyologica," Bollettino di pesca, piscialtura e idrobiologia, Vol. 2, pp. 193-205 (1947).

9. Dôtu, Y., "A new species of a goby with a synopsis of the species of the genus Luciogobius Gill and its allied genera," Journal of Faculty of Agriculture, Kyushu University, Vol. 11, pp. 69-76 (1957).

10. Gill, T. N., "Notes on a collection of Japanese fishes, made by Dr. J. Morrow," Proceedings of the Academy of Natural Sciences Philadelphia,
Vol. 11, pp. 144-150 (1859).

11. Miller, P. J., "New species of Corcyrogobius, Thorogobius, and Wheelerigobius from West Africa (Teleostei: Gobiidae)," Journal of Natural History, Vol. 22, pp. 1245-1262 (1988).

12. Okiyama, M., "Luciogobius adapel, a new species of gobiid fish from Japan," Bulletin of National Science Museum (Tokyo), Vol. 27, pp. 141-149 (2001).

13. Regan, C. T., "On a collection of fishes from the inland sea of Japan made by Mr. R. Gordon Smith," Annals and Magazine of Natural History (Series 7), Vol. 15, pp. 17-26 (1905).

14. Regan, C. T., "The fishes of the gobiid genus Luciogobius Gill," Annals and Magazine of Natural History (Series 11), Vol. 5, pp. $462-465$ (1940).

15. Sanzo, L., "Distribuzione delle papille cutanee (organi ciatiforme) e suo valore sistematico nei gobi," Mitteilungen der Zoologischen Station Neapel, Vol. 20, pp. 249-328 (1911).

16. Shiogaki, M. and Dotsu, Y., "Two new species of the genus Luciogobius (family Gobiidae) from Japan,” Japanese Journal of Ichthyology, Vol. 23 pp. 125-129 (1976).

17. Snyder, J. O., "Descriptions of new genera and species of fishes from Japan and the Riu Kiu Islands," Proceedings of the United States National Museum, Vol. 36, pp. 597-610 (1909).

18. Suzuki, T. and Shibukawa, K., "Genus Luciogobius," in: Senou, H., editor, A photographic guide to the gobioid fishes of Japan, Heibonsha Press, Tokyo (2004).

19. Suzuki, T., Shibukawa, K., and Senou, H., "Proposal of new standard Japanese names for two species of endangered gobioid fishes," Japanese Journal of Ichthylogy, Vol. 53, pp. 198-200 (2006).

20. Wongrat, P. and Miller, P. J., "The innervation of head neuromast rows in eleotridine gobies (Teleostei: Gobiidae)," Journal of Zoology, London, Vol. 225, pp. 27-42 (1991). 